\title{
Measuring Organizational Effectiveness: The Role Of The Organizational Community Index
}

Randall G. Bowden, (Email: bowdenR@universe.uiwtx.edu), University of the Incarnate Word Michael W. Mulnix, (Email: mulnix@universe.uiwtx.edu), University of the Incarnate Word

\begin{abstract}
The purpose of this research is to help understand the value of presuppositions through the development of a community index for organizations, that employees bring certain community appeals to organizational life. Those appeals are entrenched in ancestral paradigms of the past as a natural part of the human psyche (Nicholson, 1997). This research attempts to understand the appeals with the development of the Organizational Community Index (OCI) with three subscales: Measure of Influence; Sense of Belonging; and Feeling of Recognition. The subscales were developed based on previous research from the influence of anthropology, sociology, and psychology on organizational studies. One hundred and forty-six business professionals were surveyed as an initial sample. Results of reliability coefficients, skewness, and kurtosis indicated that the subscales are reliable and serve psychometric purposes. The OCI should be further tested with larger samples sizes and in a variety of organizations. Initial conclusions suggest that organizations might want to assess their sense of community among employees before they proceed with planned change involving organizational effectiveness.
\end{abstract}

\section{Introduction}

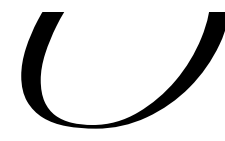

ver a decade ago Bellah, Madsen, Sullivan, Swindler, and Tipton (1991) called for a good society to experiment with democracy. To accomplish this experiment, they suggested people must understand the intimidating nature of institutions. More recently, a possible by-product of intimidation might be seen in employee turnover rates in organizations as high as $15 \%$ costing $\$ 10,000$ per employee to replace them (Luthans, 2000). Where is the good society? Is there a good society? How is it manifest in organizations? The purpose of this research is to help understand the value of presuppositions that employees bring certain community appeals to organizational life. Those appeals are entrenched in ancestral paradigms of the past as a natural part of the human psyche (Nicholson, 1997) and this research attempts to understand the appeals with the development of the Organizational Community Index (OCI).

The quest for the good society may rest at the feet of the leaders and managers of corporations. Colson and Eckerd (1991) related that organizations are responsible for more than paychecks, stock options, benefits, and bonuses. They ought to bring dignity to employees for a job well done and provide training to build individual skills that also enrich people's lives. They further related that organizations ought to develop a sense of belonging through common goals among people who work side by side. Finally, organizations provide a belief that society is better today because people went to work.

This research offers three concepts related to organizational experiences in which leaders, managers, and co-workers can provide to help enrich people's lives. In doing so, the possibility of society being a better place

Readers with comments or questions are encouraged to contact the authors via email.

because people went to work is within grasp. Certainly, organizational life is not reduced to three factors that can change a society. Theories and models engulfing organizational complexities integrated with human intricacies and 
idiosyncrasies would argue otherwise. Nevertheless, borrowing a page from Senge's (1990) perspective of nature's templates, there are significant patterns in organizational life by which a better society can be built. One pattern is beginning to emerge empirically with this study. The pattern reveals three subscales associated with it: (1) a Measure of Influence, (2) a Sense of Belonging, and (3) a Feeling of Recognition. These three subscales are being developed as the OCI (Organizational Community Index). The OCI provides a profile of business professionals as to their view of having a measure of influence, a sense of belonging, and an aspect of recognition in their jobs. One of the values of the instrument is that it will be able to be correlated with other information obtained from respondents, such as demographic data, job characteristics, job performance, personality, or attitude measures.

\section{Theoretical Construct}

This research begins to explore the development of the Organizational Community Index (OCI). Organizational community is defined as the level to which interaction is considered worthwhile as self is linked to other individuals when subsumed in a work environment. The $O C I$ is comprised of three subscales: (1) a Measure of Influence, (2) a Sense of Belonging, and (3) a Feeling of Recognition. The three subscales measure individual perspectives of interaction in the work environment. The following literature review addresses influence, belonging, and recognition predominate in a variety of scholarly fields that contribute to organizational studies and the personal aspects of each to where work might be considered worthwhile.

\section{Influence}

People expect to exhibit their influence across a spectrum of systematic systems since influence does not occur in isolated events (Heller, 1998). This is based on the convention that there is a universal tendency to want to influence. The issue becomes how much a person believes he or she has a measure of influence in his or her social setting. It would be expected that if there is very little influence, the person might consider the social setting to reflect more of a slave labor relationship (Heller, 1998). At work, a person who feels he or she does not express some influence may experience the hygiene factors of Herzberg (1988): Activities in which people engage will be those to simply sustain basic life preserving processes. To engage in other activities appears futile since no one is going to listen anyways. This is equivalent to what Spangle and Moorhead (1997) referred to as a negative communication pattern that results in poor morale and low self-esteem. In essence, people want to be heard, have a sense that what they say makes a difference.

The purpose of influence is not to exert authority from a position of power. It is the belief that a person affects views, actions, and feelings of another person or other people (Nelson \& Quick, 2000). The influence may be upward with a boss, downward with a subordinate, or lateral with a co-worker (Nelson \& Quick). Effects of influence are important ingredients in a person's organizational life. According to Spangle and Moorhead (1997), people cannot not communicate whether at work, home, or in social situations.

Communicating meets social needs. In part, it is a control mechanism in that communication is an attempt to influence other people (Spangle \& Moorhead, 1997). Although, being shunned of communication and its influence on others have adverse effects on people. People who lack contact tend to experience higher levels of physical or mental difficulties. More predominantly, the literature concerning influence has to do with patterns and tactics of influence (Falbe \& Yukl, 1992; Maslyn, Farmer, \& Fedor, 1996; Yukl, Fable, \& Youn, 1993; Yukl, Guinan, Sottolano, 1995). These are important studies and contribute a great deal to the knowledge and understanding of organizational life. Of concern here is, do those patterns and tactics have a measure of effectiveness in the sender's mind, thus, creating a more positive outlook in one's perspective of organizational life?

A Measure of Influence is defined as input by one person in the work environment resulting in selfperceived impact towards the interest of both self and others. This is a different type of concept usually describing "influence" in organizational literature. Found in the literature are tactics: rational persuasion, inspirational appeals, consultation, ingratiation, personal appeals, exchange, coalition, pressure, and legitimizing (Yukl et al., 1993). The tactics can be used for different objectives among supervisors, subordinates, and peers. These tactics are predicated on antecedent conditions: situational factors, agent characteristics, target characteristics, agent-target relationships, 
and the agent's belief system (Porter, Allen, \& Angle, 1981). In influence attempts with superiors the requests are usually portrayed as requests for approval or resources, a need of political support, or want of personal benefits (Yukl et al., 1995).

This study does not examine influence tactics or attempts but the perceived influence a person thinks he or she has with supervisors, subordinates, or peers regardless of organizational outcomes. A Measure of Influence is more aligned with what Scholl (1999) relayed as promotive control similar to a person giving good advice or helping him or her possibly find a better way to accomplish something. However, a Measure of Influence is not described as a controlling concept but more of a self-perception that one has given good advice or helped another person when one has spoken. Whether this outcome is real or not is of little consequence. The person simply believes he or she has a measure of influence. For in this instance people consider they are instrumental in shaping the community of others, what Bellah et al. (1991) phrased as "we can 'make a difference' in the institutions that have such an impact on our lives" (p. 19).

A Measure of Influence is the first subscale of the Organizational Community Index. Influence is not described in light of tactics or patterns or antecedent conditions but for self-perceived impact towards the interest of both self and others. Influence is based on a fundamental concept that individual participation in organizations is worthwhile as self is linked to other individuals. A Measure of Influence is only one subscale of the $O C I$. A second subscale is depicted as a Sense of Belonging.

\section{Belonging}

The perspective that individuals need affiliation influences the Sense of Belonging subscale of the $O C I$. Analogous to sports fans' common bond to each other and loyalty to the sporting event that brought them together, the interaction with other people with similar attachments in an organization can be a sense of a personalized role becoming a descriptor of "self" and a means to maintain self-concept (Laverie \& Arnett, 2000). A Sense of Belonging may or may not be tied to organizational values. Belonging tends to be united with the values of the people to which an individual feels a particular attachment. Certainly, it is rare that an individual gets to select his or her organizational milieu entailing issues such as gender, age, ethnic identity, expertise, education levels, social likes and dislikes, political views, family values, mores, and work ethic. Thus, there is a certain risk of not getting along with one's supervisor, subordinates, and peers by merely participating in institutions. Setting aside organizational values, goals, standards, and objectives for a moment, a Sense of Belonging is comparable to the factors underlying a township community: friendliness, care, quality of community, and alienation and acceptance (Puddifoot, 1994).

Viewing employees through the kaleidoscope of a township community is quite different than much of organizational research. The thrust of organizational studies tend to discuss the relationship of employees to the organization for greater organizational effectiveness as aligned with organizational vision, mission, objectives, values, and culture (e.g. Lau \& May, 1998). However, Organ (1988) suggested that there are functions performed by employees apart from the work itself yet are powerful contributions to the system. Employees engage in spontaneous, innovative, altruistic, courteous, and civic virtuous behaviors (Konovsky \& Pugh, 1999; Moorman, 1993; Smith, Organ, \& Near, 1983). Organ labeled these types of functions as Organizational Citizenship Behaviors (OCB). In an attempt to understand better the relationship between organizational behavior and employee behavior, the Organizational Citizenship Behavior is based on the supposition that job satisfaction may not be related to the type of performance usually measured by job satisfaction scales (Moorman, 1993). Organ (1988) and Moorman (1993) suggested, then, that there is an attitudinal (cognitive) basis for job satisfaction that is intricately woven into job functions as may be depicted in a "job description." Together, they comprise what can be measured as job satisfaction.

Given this notion of cognitive importance toward job satisfaction, researchers were sparked with a renewed interest in the topic. For example, organizational citizenship behavior studies have been associated with linking individuals to the organization and society (Tomer, 1998), providing further explanations of impression enhancing and self-serving behavior (Bolino, 1999), promoting good organizational citizenship through clearly articulated visions and values (Sloat, 1999), paying for performance (Deckop, Mangel, \& Cirka, 1999), connecting work life benefits to organizational citizenship behavior (Lambert, 2000), and relating organizational citizenship behavior to social ex- 
change theory (Konovsky \& Pugh, 1994).

Social exchange theory can explain a great deal toward the relationship between organizational and individual behavior. It involves "a return on investment." In other words, a person may behave a certain way in an organization with the expectation that he or she will receive a particular return for the behavior. Konovsky \& Pugh (1994) concluded trust is built in a supervisor-subordinate relationship when a supervisor acts on behalf of the subordinate with procedural justice issues. They further concluded that this impacts an employee's behavior. This was further substantiated by Masterson, Lewis, Goldman, and Taylor (2000). They found social exchange impacts procedural justice towards employees perceived organizational support. And, social exchange provides evidence that leader-member exchanges pertaining to affective commitment, intentions to quit, performance ratings, organizational citizenship behavior, and favor doing were related to perceived organizational support (Wayne, Shore, \& Linden, 1997). Although, Barker and Camarata (1998) related that before trust commitment and perceived organizational support take place as explained by social exchange, the role of communication is necessary for creating and maintaining relationships.

Social exchange theory is widely used to help researchers understand organizational and individual behavior. Additionally, it provides evidence for the social worth of the behaviors according to Gassenheimer, Houston, and Davis (1998). They maintained that relationships survive or fail because of the net value of the social and economic interests and dependence of those people involved. What Gassenheimer et al., in essence, did, was argue for a sense of community as a value in the working environment. This is an important point by them as previously made by Westphal and Zajac (1995). In a study of 442 corporations over 10 years, they concluded that social and psychological forces affect the inner circle of executives versus external forces of influence. This leads to a paradigmatic shift to where "evolutionary psychology offers a radical and challenging new perspective on human nature and organizational society” (Nicholson, 1997, p. 1053).

It is concluded that humans suffer the consequences of a poor fit between their inherited natures and many of the constructed environments in organizational society, but that new emerging forms of organization may present opportunities for social relations closer to the ancestral paradigms of human psychology. (p. 1053)

This, then, brings the discussion to the concept of a Sense of Belonging as the second measure of the Organizational Community Index. Although, organizational citizenship behavior and social exchange theory have received satisfactory attention and explained much of worker performance, the $O C B$ primarily pertains to employee behavior exceeding job requirements and is not explanatory of what an employee thinks of his or her co-workers as a community. Social exchange refers to future obligations based on current relationships. Nevertheless, both examine organizational behavior in light of achieving organizational objectives instead of inherited natures. However, "A person's well-being and behavior are affected both by the attributes they ascribe to themselves and by those they believe others infer about them from their organizational membership" (Dutton, Dukerich, \& Harquail, 1994, p. 241) and as an extension of their inherited natures (Nicholson, 1997). The OCI becomes a new way to look at organizational life as it is postured to take advantage of people's natural tendencies toward community.

A Sense of Belonging, therefore, is defined as a personalized role in a network comprised of kinship groups. The definition is grounded in scholarly thinking principally with social identity theory. The theory was conceptualized by Tajfel (1972) in that people belong to particular social groups in which there are emotional significance and value for being included in the group. Hogg and Terry (2000) wrote a particularly compelling article on the saliency of social identity in organizational contexts. A major component of their work included a prototypical context for one's place in the organization. Members of the group are accepted and liked more when they match the social categories and context of the group, hence its prototypical composition. Benkoff (1997) suggested this social matching is a strongly felt group identity whereby commitment to the organization, and employee performance is increased based on the strength of the identity.

For the study of organizational life, it therefore presents us with two major challenges. The first is to rethink our theoretical ambitions, to test and establish their consistencies with what we are learning about human nature. The second is to use these ideas to challenge current practice in management and organization to move toward 
forms which help us uphold the dignity of our essential natures and individuality, and in doing so help us rediscover the meaning of community in organizational life (Nicholson, 1997, p. 1070) (italics added).

The $O C I$ provides an initial entry into challenging theoretical ambitions. The three subscales of the $O C I$ are attempting to provide consistency with what we know and are learning about human nature. Additionally, the Organizational Community Index can be applied to rediscovering the meaning of community in organizations with its subscales. The first subscale, a Measure of Influence, is defined as input by one person in the work environment resulting in self-perceived impact towards the interest of both self and others. The second subscale, a Sense of Belonging, is defined as a personalized role in a network comprised of kinship groups. The next subscale also is tied to the meaning of community in organizational life.

\section{Recognition}

The Feeling of Recognition subscale of the $O C I$ is influenced by an individual's need for appreciation more deeply entrenched in a sense of self-value versus traditional organizational reward and recognition systems. Traditional reward and recognition programs feature both internal and external approaches, mainly geared at motivating employees for greater organizational effectiveness (e.g., Bursch, 1999; Herzberg, 1990; Lisoski, 1999; Parker, Adams, \& Zielinski, 2000; Schein, 1980; Waters, 1999). Benefits of recognition and rewards can include employment promotions, bonuses, pay increases, extra days off, parking places, candy bars, certificates, flex-time, movie tickets, training, stock options, compliments, pats-on-the-back, or a seemingly endless stream of suggestions. Whether rewards and recognitions are internal or external approaches, recent thinking tends to classify recognition as "programs" (e.g., Casison, 1988; Durham, 1992; HR Focus, 1999; Flynn, 1998; Hale \& Bailey, 1998; Lisoski, 1999; Spitzer, 1996; Sunnarborg, 2000).

Whatever the approach or program, the focus on the employee tends to be secondary. The major concern of a company is to boost production, profits, or whatever the bottom-line is for a company. Hopefully this is completed with a contented workforce. Nevertheless, the focus on employees tends to be secondary in nature until discontentment begins to affect the bottom line. Turnover rates hover around $15 \%$ mainly because of a lack of employee commitment, which in turn, costs companies approximately $\$ 10,000$ per employee to replace (Luthans, 2000). Even seemingly good rewards and recognitions can have an adverse affect on employees because they lack value, or are generic, or target irrelevant things, or are systematic to the point of insignificance (Nelson \& Quick, 2000; Spitzer, 1996). Although the intentions of organizations may be admirable by implementing recognition programs, the central focus tends to remain, ultimately, on the "good of the organization" not the good of the employee, thus a superficial appreciation can emerge. This is not to suggest advocating a bowing to the whims and whines of employees. It only suggests that many current programs of recognitions and rewards may be indicative of demonstrating to employees what the organization thinks is important instead of understanding what the employees think is essential for recognition. Additionally, what these programs may create is a sense of entitlement, eventually defeating the purpose of a reward and recognition program. In 1995, Wright-Hennepin Cooperative Electric Association, in an attempt to vie for employees and their loyalty in a competitive market, developed a performance bonus plan. One major concern of board members and management representatives was to establish the plan, definitively, as a reward not an entitlement as they stated. It was approved and implemented that same year (Vogt, 1995).

A Feeling of Recognition is defined as a personal impression as though one's contribution is genuinely appreciated by the informal acknowledgment from other people. The notion of a feeling of recognition is a basis for "'socially responsible organizations,' where dignity and respect are possible both inside and outside the company" (Seiling, 1999, p. 16). Sonnenberg and Goldberg (1992) understood this almost a decade ago when they indicated that the new bottom line means treating people with dignity and respect because both businesses and society lose something tangible when they are abandoned. Unfortunately for organizations and individuals, there are no formulas, systems, programs, certifications, or formalities about how to treat people with dignity and respect (Holoviak, 1993). This type of behavior would seem obvious, but organizations are replete with people who tell horrifying stories of mistreatment. So, to turn recognition into a formula, or system, or program, or certification, or formality may defeat the purpose of dignity and respect. Simply stated, employees will be disenchanted and deviate from organizational purposes (Fox, Byrne, \& Rouault, 1999) without being treated with dignity and respect showing up as genuine 
appreciation (Afholderbach, 1998) because they feel they deserve better treatment or they will look elsewhere for employment (Staton, 1997). Together, a Measure of Influence, a Sense of Belonging, and a Feeling of Recognition constitute the Organizational Development Index; they are defined as, input by one person in the work environment resulting in self-perceived impact towards the interest of both self and others; personalized role in a network comprised of kinship groups; personal impression as though one's contribution is genuinely appreciated by the informal acknowledgment from other people, respectively. Jointly, they comprise the OCI, which is defined as the level to which interaction is considered worthwhile as self is linked to other individuals when subsumed in a work environment.

\section{Instrument Development}

The current survey to measure organizational community evolved as an instrument primarily because of the interaction of business faculty, including myself, with adult students who were in graduate business programs and undergraduate degree completions programs. Additionally, permission was granted to faculty, business professionals, and consultants to use the $O C I$ in their consulting and organizational development endeavors in the Southwest and on the East coast. The items selected for the $O C I$ were developed as statements based on comments made by business professionals, business faculty, and writings from research over a seven-year time frame. The statements were arranged into three subscales according to emergent themes and research. The subscales were labeled on the basis of prior research from organizational studies as influenced by psychology, sociology, and anthropology. The labels of the subscales are established as follows: (1) a Measure of Influence, (2) a Sense of Belonging, and (3) a Feeling of Recognition.

A pilot instrument composed of the three subscales includes 23 items. The Measure of Influence subscale contains seven items. The Sense of Belonging subscale contains eight items. The Feeling of Recognition subscale contains eight items. All items were randomly distributed on the instrument. Participants were asked to respond to items on a four-point scale. The scale ranged from "strongly agree," to "mildly agree," to "mildly disagree," to "strongly disagree" with strongly agree valued at "4" and strongly disagree valued at "1."

The Organizational Community Index is comprised of the three subscales. An example statement of the Measure of Influence subscale is, "At work, often someone expresses how grateful he or she is for the assistance I provide." An example statement of the Sense of Belonging subscale is, "I feel at ease with the people I work with." An example statement of the Feeling of Recognition subscale is, "Co-workers generally appreciate what I do on the job."

Establishing the $O C I$ as a viable instrument to use for organizational studies, consulting, and planned change, statistical analysis was crucial to the process. Statistical analysis was completed by reliability coefficients, and skewness and kurtosis for psychometric purposes (George \& Mallery, 2001). Demographic data were also collected for comparisons, primarily for use at a later time. Data were gathered among professionals representing a variety of businesses.

\section{Sample}

The sample selected for initial results were MBA and graduate management students at a Southwestern university and at two businesses in the Southwest where consultants asked to use the $O C I$ to help them understand their respective clients' phenomenon. Two large corporations on the east coast asked for permission to use the instrument, and permission was granted. At the time of this writing, one company in the Southwest distributed the instrument but was waiting on permission to release the information for proprietary reasons. One corporation on the east coast had to cancel the distribution of the instrument until it can be determined when the best time will be to complete the survey. At the time of writing this paper, employees of the second corporation are to receive distribution of the instrument when the consultant provides final scheduling. In the meantime, it was felt that the current distribution was a sufficient sample to provide initial results.

The $O C I$ was distributed to MBA and management students over a two-month period in three separate 
courses. The total number of respondents from the three courses was 37 individuals. The total number of respondents from industry was 109 of 150 from upper management to office workers, and surveys were distributed during the same two-month period from February through March 2001. The total number of respondents, then, was 146. All respondents were provided a cover letter indicating the nature of the survey and the potential use of the results. Further, the letter indicated that participation was entirely voluntary and by completing the survey it was acknowledgement of their permission to use the data that might result from the research.

The difficulty of generalization to larger populations is inherent in the current sample. Although the method in this research was convenience sampling, it does, however, characterize a broad range of people and professions of which the participants represent. In probability sampling, the "ultimate purpose of survey sampling is to select from a set of elements from a population in such a way the descriptions of those elements (statistics) accurately describe the total population from which they are selected" (Babbie, 1990, p. 75). Given the design of the survey to be used in the actual organizational world, and given the analytical power of statistics, testing of the important propositions of the $O C I$ provides strong initial results and fundamental contributions toward the "challenge [of] current practice in management and organization[s] to move toward forms which help us uphold the dignity of our essential natures and individuality" (Nicholson, 1997, p. 1070).

\section{Results}

Data were analyzed using the Statistical Package for the Social Sciences, Release 10.0 for Windows. The results are represented in three areas: (1) general demographics, (2) reliability coefficients, and (3) skewness and kurtosis. The major areas of concern regarding the results are reliability coefficients, skewness, and kurtosis.

\section{General Demographics}

General demographics, although the data were collected primarily for future analysis, provide broad categories for generalization and demonstrate a representation of professions. The data were collected in a variety of areas and reported in the following: type of industry, one's current position, number of years in current position, and number of hours worked per week. Relevant data for this paper regarding demographics is represented in Table 1.

Table 1

General Demographics of Respondents Who Completed the OCI $\mathrm{N}=146$

$\begin{array}{lrr} & \underline{\mathrm{n}} & \underline{\text { Percent }} \\ \text { Type of Industry } & & \\ \text { Finance, insurance, real estate } & 20 & 13.7 \\ \text { Forestry, fisheries, mining } & 1 & .7 \\ \text { Services } & 14 & 9.6 \\ \text { Tourism } & 1 & .7 \\ \text { Technology } & 2 & 1.4 \\ \text { Manufacturing } & 1 & .7 \\ \text { Government } & 9 & 6.2 \\ \text { Communications } & 7 & 4.8 \\ \text { Education } & 5 & 3.4 \\ \text { Other } & 86 & 58.9\end{array}$

General Demographics of Respondents Who Completed the OCI

$\begin{array}{lll} & \underline{\mathrm{n}} & \text { Percen } \\ \text { Current Position } & & \\ \text { Executive VP } & 1 & .7 \\ \text { VP } & 1 & .7 \\ \text { Senior. Director } & 5 & 3.4\end{array}$




\author{
Mid Director \\ Junior. Director \\ Senior. Manager \\ Mid Manager \\ Junior Manager \\ Supervisor \\ Other \\ Missing
}

Number of Years in Current Position

Less than one year

1 to 2

$2+$ to 4

$4+$ to 6

$6+$ to 8

$8+$ to 10

$10+$ to 12

$12+$ to 14

$14+$

Number of Hours Work Per Week
Currently unemployed
Less than 10
10 to 15
16 to 20
26 to 30
31 to 35
36 to 40
40 to 45
46 to 50
51 to 55
more than 55

$\begin{array}{rr}6 & 4.1 \\ 1 & .7 \\ 4 & 2.7 \\ 14 & 9.6 \\ 7 & 4.8 \\ 27 & 18.5 \\ 78 & 53.4 \\ 2 & 1.4\end{array}$

22

15.1

$$
31.5
$$$$
24
$$

11.6

8.2

1.4

2.7

.7

4

$\begin{array}{rr}20 & 13.7 \\ 1 & .7 \\ 1 & .7 \\ 2 & 1.4 \\ 2 & 1.4 \\ 1 & .7 \\ 32 & 21.9 \\ 78 & 53.4 \\ 17 & 11.6 \\ 5 & 3.4 \\ 2 & 1.4\end{array}$

These results indicate a large number of respondents selecting "other" for both "type of industry" and "current position." Although demographics are not an element of the $O C I$, they do provide noteworthy information for further analysis. It appears from this sample, the demographic categories need to be expanded to include other options. "Number of years in current position" information was collected more for curiosity sake. The thoughts behind this variable indicate that low morale or low scores in $O C I$ subscales could be correlated to lack of movement in the position. However, to do this at this point would be getting ahead of the research. Nevertheless, data are being collected for future reference. Finally, as an indicator that the sample was indeed appropriate, "number of hours per week" data were collected. The indication is that a sufficient number of respondents are working full time with several not presently working. Those not working were given further instructions to think of their previous position and complete the survey. Since $93.8 \%$ of the respondents were between the ages of 25 and 55 , the data for those respondents not working were included in the initial results. Overall, the demographic data demonstrate a good background of participants for further analysis of the $O C I$.

\section{Reliability Coefficients}

The creation of an instrument designed with consequential decision-making in mind should be able to withstand statistical scrutiny. The $O C I$ was distributed to business professionals and reliability coefficients were run to help determine its degree of consistency. Although reliability is a function of sampling, the results indicate a high reliability with the current sample. The data are represented in Tables 2, 3 and 4 for each of the subscales.

Table 2

Reliability Coefficients of a Measure of Influence

$\mathrm{N}=143$ 


\begin{tabular}{|c|c|c|c|}
\hline Item & $\underline{\text { Mean }}$ & $\underline{\mathrm{SD}}$ & Alpha if Item Deleted \\
\hline Influence Item 1 & 3.29 .58 & & .75 \\
\hline Influence Item 2 & 3.35 .62 & & .70 \\
\hline Influence Item 3 & 3.22 .63 & & .71 \\
\hline Influence Item 4 & 3.04 .72 & & .70 \\
\hline Influence Item 5 & 2.76 .81 & & .80 \\
\hline Influence Item 6 & 3.08 .68 & & .70 \\
\hline Influence Item 7 & 3.04 .76 & & .74 \\
\hline
\end{tabular}

The Measure of Influence subscale of the $O C I$ was found to be reliable with the sample. With an alpha level of .76, the seven-item subscale can be used to measure input by one person in the work environment resulting in selfperceived impact towards the interest of both self and others. Although the results indicate deleting item five from the subscale can increase the alpha level to .80 , the seven-item scale provides a strong measure of influence. As with any sample, the alpha level and alpha if item deleted results must be examined in order to determine the applicability and generalizability of the instrument, or subscale, to a population. 
Table 3

Reliability Coefficients of a Sense of Belonging

$\mathrm{N}=146$

Item $\quad \underline{\text { Mean }} \quad \underline{\text { Alpha if Item Deleted }}$

$\begin{array}{llll}\text { Belonging Item } 1 & 3.40 & .65 & .72\end{array}$

$\begin{array}{llll}\text { Belonging Item 2 } & 3.37 & .67 & .73\end{array}$

$\begin{array}{llll}\text { Belonging Item } 3 & 3.51 & .69 & .76\end{array}$

$\begin{array}{llll}\text { Belonging Item } 4 & 3.31 & .82 & .75\end{array}$

$\begin{array}{llll}\text { Belonging Item } 5 & 3.32 & .68 & .71\end{array}$

$\begin{array}{llll}\text { Belonging Item } 6 & 3.41 & .70 & .75\end{array}$

$\begin{array}{llll}\text { Belonging Item } 7 & 3.35 & .71 & .74\end{array}$

$\begin{array}{llll}\text { Belonging Item } 8 & 3.50 & .67 & .75\end{array}$

Alpha $=.77$

The Sense of Belonging subscale of the $O C I$ was found to be reliable with the sample. With an alpha level of .77, the eight-item subscale can be used to measure a personalized role in a network comprised of kinship groups. The results indicate a strong reliability coefficient among items and nothing is to be gained by deleting items as they relate to this sample. The eight-item subscale provides a strong measure of belonging.

Table 4

Reliability Coefficients of a Feeling of Recognition

$\mathrm{N}=146$

$\underline{\text { Item }} \quad \underline{\text { Mean }} \quad \underline{\text { SD }} \quad \underline{\text { Alpha if Item Deleted }}$

$\begin{array}{lll}\text { Recognition Item 1 } & 3.32 .65 & .82 \\ \text { Recognition Item 2 } & 3.06 .74 & .81 \\ \text { Recognition Item 3 } & 3.01 .68 & .80 \\ \text { Recognition Item 4 } & 3.05 .75 & .82 \\ \text { Recognition Item 5 } & 3.33 .62 & .82 \\ \text { Recognition Item 6 } & 3.01 .65 & .81 \\ \text { Recognition Item 7 } & 3.20 .94 & .85 \\ \text { Recognition Item 8 } & 3.00 .70 & .82 \\ & & \end{array}$

The Feeling of Recognition subscale of the $O C I$ was found to be reliable with the sample. With an alpha level of .84, the eight-item subscale can be used to measure a personal impression as though one's contribution is genuinely appreciated by the informal acknowledgment from other people. The results indicate a strong reliability coefficient among items and little is to be gained by deleting items (possibly item 7) as they relate to this sample. The eight-item subscale provides a strong measure of recognition.

Together, the three subscales of the $O C I$ reveal the level to which interaction is considered worthwhile as self is linked to other individuals when subsumed in a work environment. A Feeling of Recognition performed as the strongest of the subscales. This could be due to the items themselves and how people come to believe the importance of recognition in their organizational life. Whereas, thinking about influence and belonging, although common to a community, may be less thought of in reference to an organization. Nevertheless, the impact of this natural thinking may be apparent in organizational life.

Skewness and Kurtosis 
According to George and Mallery (2001) skewness and kurtosis can be excellent indicators for psychometric purposes. In attempting to establish an instrument to "challenge [a] current practice in management and organization[s] to move toward forms which help us uphold the dignity of our essential natures and individuality" (Nicholson, 1997, p. 1070), the psychometric purpose is a necessity to analyze. The data are represented in Table 5.

Table 5

Skewness and Kurtosis of a Measure of Influence, Sense of Belonging, and Feeling of Recognition $\mathrm{N}=146$

$\begin{array}{lccccc}\text { Item } & \underline{\mathrm{n}} & \underline{\text { Mean }} & \underline{\mathrm{SD}} & \underline{\text { Skewness }} & \underline{\text { Kurtosis }} \\ \text { Influence } & 143 & 3.11 .44 & -.57 & .59 \\ \text { Belonging } & 146 & 3.40 .43 & -1.24 & 2.09 \\ \text { Recognition } & 146 & 3.12 .50 & -.63 & .62\end{array}$

The data indicate a mixture of psychometric results. George and Mallery (2001) indicated that both skewness and kurtosis values between positive and negative 1.0 are considered excellent. Even values between positive and negative 2.0 are considered acceptable depending on the application. Results for both influence and recognition indicate excellent psychometric values. The negative skewness of the subscales indicates a greater number of larger values. Although belonging exceeds a value of -1 , it may be considered relatively strong to measure a personalized role in a network comprised of kinship groups when viewed with the reliability coefficient (.77). Additionally, a kurtosis value of 2.02 indicates a flat distribution but is not considered extreme (> 5.0). Again, considering the strength of the reliability coefficient, the belonging subscale is observed to be psychometrically accurate with the current sample.

In general, the statistics tend to support the $O C I$ as a reliable instrument. The basis of the $O C I$ begins with the presupposition that employees bring certain community appeals to organizational life. Although those appeals are entrenched in ancestral paradigms of the past as a natural part of the human psyche (Nicholson, 1997), they are not discarded, set aside, or forgotten when one enters organizational life. The purpose of this research is to help understand the value of those appeals through the development of a community index for organizations, as they may be present in employees to a greater extent than what might have been observed previously in organizational research.

\section{Discussion}

The importance of ancestral appeals involving dignity and respect in organizational life is that there can be a natural appeal to people's inherent sense of value. If people naturally gravitate toward "community," it stands to reason an organization could develop employee incentives parallel to this idea of community. Understandably, an organization is not a community, however people tend to exhibit community patterns in their organizational life. Even a casual observer of organizational behavior can notice how people drift to and associate with those people similar to themselves. Grasping these patterns provide organizations insight into structuring programs, processes, or other organizational considerations to sustain or improve effectiveness. The following discussion addresses the issues of organizational community in the areas of a Measure of Influence, a Sense of Belonging, and a Feeling of Recognition.

\section{Measure of Influence}

Input by a person in the work environment resulting in self-perceived impact towards the interest of both self and others describes a measure of influence. The results of research of this construct indicate employees have a need to express themselves to where they believe they are instrumental in shaping the community of others in the work environment. The importance of this measure was studied by Ibarra and Andrews (1993) only in reverse form. They concluded that network factors shape job perceptions more than a person's formal position or department affiliation to where seeking advice for decision-making extended from the closeness a person felt to another (the network 
centrality construct). The subscale, a Measure of Influence, asserts the reverse of this relationship of closeness: People whose advise is being sought will perceive they have measure of influence and thus feel they belong to the organizational community. They will be connected to the organization through their social community sub-culture as naturally developed in the organization.

Although the network centrality construct provides impetus to the $O C I$, albeit an opposite appearance, the Measure of Influence component subsumes a deeper social value. It suggests the importance of the person in the community as a valued member. People genuinely appreciate what this person has to say or offer. Furthermore, Kanter (2000) related that valuing people is a key element of the future. Leonard (2000) indicated that America's work ethic "is more than simply a work/life issue, however, in that a basic American social value of more hard work is being transformed into "work smart but do not forget your other life obligations"” (p. 224). The inference is that the social network of people's lives does not end at the beginning of the workday. People remain connected to a community and tend to transfer the basic elements of those communities to the job. One of those basic elements of community is that a person is not being ignored or disregarded by his or her peers, subordinates, and supervisors, or others who constitute the organizational community. "People resent it when others look through or past them" (Weiss, 1997, p. 3). People want to feel that they have a measure of influence toward others and not experience being a "nobody."

Unfortunately, when dealing with the concept of influence, the majority of research defaults to a discussion of power, which affects the behavior or thoughts or feelings of someone else. Given this common view even a stoplight exhibits power/influence. Certainly there is a facet of which influence is synonymous with power. Overall, the lack of research pertaining to a measure of influence as it relates to a basic need to belong to a community makes it difficult to draw substantial conclusions. In part, it is a phenomenon seemingly difficult to conceptualize and measure empirically. Moreover, researchers from an organizational perspective are not necessarily accustomed to examining effectiveness in light of social community composition. Nevertheless, Troyer and Younts (1997) believed that "interaction is assumed to be guided by three motives: contributing to group performance, preserving status, and facilitating interaction" (p. 692). They concluded social interaction is the adjustment of a person's behavior to match in a meaningful way to the expectations of others. This comes in a context where a person reads the interpretations of others and makes the necessary adjustments to contribute in a meaningful way. All in all, the contribution provides a measure of influence.

A Measure of Influence as a subscale of the $O C I$ leads researchers to explore more fully the relationships between people at work as a community. It calls for organizational researchers to explore anthropological, psychological, and sociological connections between work and how people make sense of it based on a need to contribute to community values that may be develop by an organization. This approach may be deemed as a drastic departure from traditional advances in organizational theory with its major premise--getting employees to buy into corporate values. An alternate approach is to begin with the basic values inherent in a community and build corporate values among those. As a result, it may be more cost effective and less difficult to design organizational systems around a natural sense of community than to do a sell job to employees as to what organizations think is valuable. Value may already be inherent in the community. Employees may need an avenue to feel influential and a setting where they have a sense of belonging.

\section{Sense of Belonging}

A personalized role in a network comprised of kinship groups describes a sense of belonging. The results of this investigation indicate employees have a strong sense of affinity or association with other people in the organization. The flipside of this can be characterized as a feeling of being ostracized, usually by being ignored. According to Williams and Sommer's (1997, p. 693) research on "the effects of social ostracism on individuals' subsequent contributions to a group task," they concluded: "Engaging salient social identities could serve two purposes: (a) to reestablish ostracized individuals' sense of belonging to important others and (b) to allow them to deflect the blame toward self to blame toward group membership, thus diffusing the impact" (p. 674). The result of depriving someone of his or her sense of community has several fallout effects. According to Williams and Sommer (1997), it deprives individuals of a sense of belonging to others. This is a need that is emotionally sought after and something 
evolutionarily adaptive. The need to belong is a primary human motivation to help guide cognition and lead to beneficial outcomes. Another effect of belonging deprivation is the difficulty to maintain high self-esteem and believe that people are good and worthy. A third effect is a sense of belonging contributes to influence with others. It gives people a point of self-efficacy to help preserve psychological well-being through a connection with others. Finally, the effects of being deprived of a sense of belonging by repeated exposure to being ostracized is people begin to question whether their existence is of consequence.

Creating a sense of belonging is not necessarily a matter of designing and implementing an organizational program to improve employee effectiveness. Belongingness is not a program, but part of the social structure of being human. Simple common courtesies may go a long ways to provide an atmosphere of community at work. Sonnenberg and Goldberg (1992) may have said it best:

In business, the new bottom line means you don't jump down someone's throat when they [sic] make a mistake; you make it clear you know when they're trying to do their best-and they will respond in kind. It also means you don't just hire bodies: You seek valued employees to join to your business family. You invest in people. Your responsibilities go beyond the next quarter's financials to build a legacy for those who follow. ( $p$. 4)

The reality is, though, organizations must pay attention to both next quarter's financials and beyond as well as investments in people. Neither should be sacrificed for the health of the organization. Unfortunately, through many cycles of downsizing blamed on economic factors, employees feel that organizations see themselves as quickly replaceable commodities (Verespej, 2001). Incredibly enough, some organizations just do not treat people with dignity and respect as a general business practice. Other organizations appear to work toward the benefit of their employees until financial troubles appear. At such a point, employees tend to be the first commodity cut along with many recognition programs. It is difficult to conceive of a sense of belonging when people have been subjected to poor organizational practices for so many years. Remarkably, depriving someone of his or her sense of community even constitutes "a withdrawal of attention or recognition by others" (Williams \& Sommer, 1997, p. 694).

\section{Feeling of Recognition}

A personal impression as though one's contribution is genuinely appreciated by the informal acknowledgment from other people describes a feeling of recognition. The results of this research indicate employees not only have a measure of influence and a sense of belonging, but to help fulfill the sense of community, they also perceive their work is recognized by other people in the organization. The recognition sought is not a matter of formal programs. It is an extension of true gratitude for providing valued insight, advice, recommendations, or other input. The recognition is unsolicited and non-competitive in nature. People are truly appreciative of a person's contribution and demonstrate gratitude.

Recognition is a vital part of the human experience. "In his Principles of Psychology, William James (1890) wrote a powerful indictment":

A man's [person's] Social Self is the recognition which he gets from his mates. We are not only gregarious animals, liking to be in sight of our fellows, but we have an innate propensity to get ourselves noticed, and noticed favorably, by our kind. No more fiendish punishment could be devised, were such a thing physically possible, than that one should be turned loose in society and remain absolutely unnoticed by all the members thereof. If no one turned round when we entered, answered when we spoke, or minded what we did, but if every person we met cut us dead, and acted as if we were nonexisting things, a kind of rage and impotent despair would ere long well up in us, from which the cruelest bodily tortures would be a relief; for these would make us feel that, however bad might be our plight, we had not sunk to such a depth as to be unworthy of attention at all. (James, 1890, pp. 293-294) (Williams \& Sommer, 1997). 
Well over 100 years ago, it was noted that recognition is a vital part of humanity. This aspect of recognition is no less important today in organizations. One of the more arduous tasks a person might have is that of fundraising - asking people to reach deep into their finances and relinquish money for a cause. Yet, Maude (1999) wrote, "Unexpected expressions of gratitude are very powerful, and they make a lasting impression" (p. 32). People are willing to give, not just financially, of their resources, of themselves, if they are appreciated.

This is what makes recognition so powerful. An unexpected display of gratitude is what leaves a lasting impression. The gifts, plaques, promotions, pay increases, bonuses, incentives, and other recognitions are important. Somewhere along the protracted list of formal recognition plans and programs, someone should stop and show gratitude to those people who are a part of the organizational community. The gestures need not be grand exhibits of pomp and circumstance. "[S]aying 'thank you' to employees regularly, with meaning and sincerity, pays big financial and psychological dividends" (Sander, 1998, p. 131).

A feeling of recognition for one's contributions is an important aspect of society. Each person has a role and people believe their role is significant, their contribution - worthy of respectable mention, their involvementadmirable for recognition, and they are. This does not mean that a simple, well placed, heart felt "thank you" will replace recognition programs and plans. It will not. It reflects the perspective that employees are not being placated when handed a recognition for which they most likely earned or were owed, anyways. It helps demonstrate that they are valued members of a community.

\section{Conclusion}

The Organizational Community Index was conceptualized from the viewpoint that people desire, seek, and expect inclusion into a community. That fundamental sense of community carries into the workforce. The workforce, generally, carries a different perspective. It creates a culture based on other types of underlying principles. These principles tend to be financial accountability in nature, whether it is to stockholders, or partners, or government agencies, or stakeholders. Although, the financial stability of an organization is important to the fiscal interests of individuals, it does not provide a more complete milieu to sustain the well being of employees. Therefore, companies often pursue programs and processes to encourage employees to commit themselves to organizational values. The hope is to create a satisfied workforce that will become organizationally more effective. The fundamental principle possibly missing in this equation is the innate sense of community to which people naturally pursue.

The $O C I$ is an instrument to measure the level of community that organizations might have as a part of doing business. A Measure of Influence, a Sense of Belonging, and a Feeling of Recognition, were established as three subscales of the $O C I$ and grounded in previous research pertaining to a sense of community. The literature contributing to the development of the subscales related to anthropology, psychology, and sociology, all of which many organizational studies rely for organizational understanding (French \& Bell, 1994; Nelson \& Quick, 2000). The initial results of the $O C I$ indicate the appropriateness of viewing organizations as a community. It is hoped the $O C I$ will provide theorists, researchers, and practitioners an avenue to understand further the complexities of the workforce and its behavior in organizations.

\section{References}

1. Afholderbach, S. E. (1998). Supervisory techniques: A supervisor's perspective. Supervision, 59 (6), 1113.

2. Anonymous. (1999). Employee input can maximize recognition/reward program success. Hr Focus, 76 (11), 15.

3. $\quad$ Babbie, E. (1990). Survey research methods (2 $2^{\text {nd }}$ ed.). Belmont, CA: Wadsworth.

4. Barker, R. T., \& Camarata, M. R. (1998). The role of communicating in creating and maintaining a learning organization: Preconditions, indicators, and disciplines. Journal of Business Communication, 35 (4), 443-467.

5. Bellah, R. N., Madsen, R., Sullivan, W. M., Swindler, A., \& Tipton, S. M. (1991). The good society. New 
York: Alfred A. Knopf, Inc.

6. Benkhoff, B. (1997). A test of the HRM model: Good for employers and employees. Human Resources Management Journal, 7 (4), 44-60.

7. Birley, A. (1987). Marcus Aurelius: A biography. New Haven: Yale University Press.

8. Bolino, M. C. (1999). Citizenship and impression management: Good soldiers or good actors? Academy of Management Review, 24 (1), 82-98.

9. Bursch, J. (1999). Well-structured employee reward/recognition programs yield positive results. HR Focus, $76(11), 1,14$.

10. Casison, J. W. (1998). Will the trend toward virtual offices make traditional reward and recognition programs obsolete? Incentive, 172 (10), 54.

11. Colson, C., \& Eckerd, J. (1991). Why America doesn't work. Dallas: Word Publishing.

12. Cooper, L. (Translator). (1932). The rhetoric of Aristotle. New York: Appleton-Century-Crofts.

13. Cummings, T. G., \& Worley, C. G. (2001). Organization development and change, ( $7^{\text {th }}$ ed.). Cincinnati: South-Western College.

14. Deckop, J. R., Mangel, R., \& Cirka, C. C. (1999). Getting more than you pay for: Organizational citizenship behavior and pay-for-performance plans. Academy of Management Journal, 42 (4), 420-428.

15. Durham, M. P. (1992). Award recognition and incentive programs reward companies, too. Human Resources Professional, 4 (4), 8-12.

16. Dutton, J.E., Dukerich, J.M., \& Harquail, C.V. (1994). Organizational images and member identification. Administrative Science Quarterly, 39 (2), 239-263.

17. Falbe, C. M., \& Yukl, G. (1992). Consequences for managers of using single influence tactics and combinations of tactics. Academy of Management Journal, 35 (3) 638-652.

18. Flynn, G. (1998). Focus and flexibility: Prudential's rewards and recognition program in action. Workforce, 77 (7), 34 .

19. Fox, D., Byrne, V., \& Rouault, F. (1999). Performance improvement: What to keep in mind. Training \& Development, 53 (8), 38-40.

20. French, W. L., \& Bell, C. H. (1994). Organization development: Behavioral science interventions for organization improvement. Englewood Cliffs, NJ: Prentice Hall.

21. Gassenheimer, J. B., Houston, F. S., \& Davis, C. J. (1998). The role of economic value, social value, and perceptions of fairness in interorganizational relationship retention decisions. Journal of the Academy of Marketing Science, 26 (4), 322-337.

22. George, D., \& Mallery, P. (2001). SPSS ${ }^{\circledR}$ for Windows ${ }^{\circledR}:$ A simple guide and reference, 10.0 update. Boston: Allyn and Bacon.

23. Hackman, M. Z., \& Johnson, C. E. (1996). Leadership: A communication perspective, $2^{\text {nd }}$ ed.). Prospect Heights, IL: Waveland Press.

24. Hale, J., \& Bailey, G. (1998). Seven dimensions of successful reward plans. Compensation \& Benefits Review, 30 (4), 71-77.

25. Harris, P. R. (1998). The new work culture: HRD transformational management strategies. Amherst, MA: HRD Press.

26. Hersey, P., Blanchard, K. H., Johnson, D. E. (1996). Management of organizational behavior, ( $7^{\text {th }}$ ed.). Upper Saddle River, NJ: Prentice Hall.

27. Herzberg, F. (1990). Herzberg on motivation. Industry Week. Penton Publications.

28. Hillman, J. (1995). Kinds of power: A guide to its intelligent uses. New York: Doubleday.

29. Hogg, M. A., \& Terry, D. J. (2000). Social identity and self-categorization processes in organizational contexts. Academy of Management Review, 25 (1), 121-140.

30. Holoviak, S. J. (1993). Golden rule perspective. Executive Excellence, 10 (11), 5-6.

31. Ibarra, H., \& Andrews, S. B. (1993). Power, social influence, and sense making: Effects of network centrality and proximity on employee perceptions. Administrative Science Quarterly, 38 (2), 277-303.

32. Kanter, R. M. (2000). Knowledge exchange. Executive Excellence, 17 (11), 3-4.

33. Khoury, A. E. (2001). The hidden dimensions of leadership success: Implications for building effective leaders. Management Development Forum, 3 (2) 141-154.

34. Williams, K. D., \& Sommer, K. L. (1997). Social ostracism by coworkers: Does rejection lead to loafing or compensation? Personality \& Social Psychology Bulletin, 23 (7) 693-706. 
35. Konovsky, M. A., \& Pugh, D. S. (1994). Citizenship behavior and social exchange. Academy of Management Journal, 37 (3), 656-669.

36. Lambert, S. J. (2000). Added benefits: The link between work-life benefits and organizational citizenship behavior. Academy of Management Journal, 43 (5), 801-815.

37. Lau, R. S. M., \& May, B. E. (1998). Win-win paradigm for quality of work life and business performance. Human Resource Development Quarterly, 9 (3), 211-226.

38. Laverie, D. A., \& Arnett, D. B. (2000). Factors affecting fan attendance: The influence of identity salience and satisfaction. Journal of Leisure Research, 32 (2), 225-247.

39. Leonard, S. (2000). Is America's work ethic changing? HRMagazine, 45 (4), 224.

40. Lisoski, E. (1999). Five key success factors of outstanding recognition programs. Supervision, 60 (9), 7 9.

41. Luthans, K. (2000). Recognition: A powerful, but often overlooked, leadership tool to improve employee performance. Journal of Leadership Studies, 7 (1) 31-38.

42. Maslyn, J. M., Farmer, S. M., \& Fedor, D. B. (1996). Failed upward influence attempts: Predicting the nature of subordinate persistence in pursuit of organizational goals. Group \& Organization Management, 21 (4) 461-480.

43. Masterson, S. S., Lewis, K., Goldman, B. M., \& Taylor, M. S. (2000). Integrating justice and social exchange: The differing effects of fair procedures and treatment on work relationships. Academy of Management Journal, 43 (4), 738-748.

44. Maude, M. R. (1999). On gratitude. Fund Raising Management, 30 (7), 32-33.

45. Moorman, R. H. (1993). The influence of cognitive and affective based job satisfaction measures on the relationship between satisfaction and organizational citizenship behavior. Human Relations, 46 (6), 759776.

46. Nelson, D. L., \& Quick, J. C. (2000). Organizational behavior: Foundations, realities, and challenges ( ${ }^{\text {rd }}$ ed.). Cincinnati: South-Western.

47. Nicholson, N. (1997). Evolutionary psychology: Toward a new view of human nature and organizational society. Human Relations, 50 (9), 1053-1078.

48. Organ, D. W. (1988). Organizational Citizenship Behavior: The good soldier syndrome. Lexington, MA: Lexington Books.

49. Parker, G., Adams, J., \& Zielinski, D. (2000). Reasons to celebrate. Incentive 174 (9), 96-97.

50. Porter, L. W., Allen, R. W., \& Angle, H. L. (1981). The politics of upward influence in organizations. In B. M. Shaw \& L. L. Cummings (Eds.), Research in organizational behavior (Vol. 3, pp. 109-149). Greenwich, CT: JAI.

51. Pudifoot, J. E. (1994). Community identity and sense of belonging in a Northeastern English town. The Journal of Social Psychology, 134 (5), 601-608.

52. Sander, W. (1998). Recognition, gratitude \& celebration. Quality Progress. 31 (5), 131-133.

53. Schein, E. (1980). Organizational psychology ( $3^{\text {rd }}$ ed.). Englewood Cliffs, NJ: Prentice Hall.

54. Scholl, W. (1999). Restrictive control and information pathologies in organizations. Journal of Social Issues, 55 (1) 101-121.

55. Schonberger, R. J. (1994). Human resource management lesson from a decade of total quality management and reengineering. California Management Review, 36 (4), 109-123.

56. Seiling, J. G. (1999). Reaping the rewards of rewarding work. Journal for Quality \& Participation, 22 (2), 16-20.

57. Senge, P. (1990). The fifth discipline: The art and practice of the learning organization. New York: Doubleday Currency.

58. Sloat, K. C. M. (1999). Organizational citizenship. Professional Safety, 44 (4), 20-23.

59. Smith, C. A., Organ, D. W., \& Near, J. P. (1983). Organizational citizenship behavior: Its nature and antecedents. Journal of Applied Psychology, 68, 653-663.

60. Sonnenberg, F. K., \& Goldberg, B. (1992). New bottom lines. Executive Excellence, 9 (12), 3-4.

61. Spangle, M., \& Moorhead, J. (1997). Interpersonal communication in organizational settings: Communication skills for business and professional success. Dubuque, IA: Kendall/Hunt.

62. Spitzer, D. R. (1996). Power rewards: Rewards that really motivate. Management Review, 85 (5), 45-50.

63. Stanton, B. (1997). Some essentials for management. Fleet Equipment, 23 (1), 41-41. 
64. Sunnarborg, R. K. (2000). 10 tips how to build a stronger recognition system. Potentials in Marketing, 33 (12), 18.

65. Tajfel, H. (1972). Social categorization. (English translation of La categorization sociale). In S. Moscovici (Ed.), Introduction er la psychologie sociale (Vol 1), pp. 272-302. Paris: Larousse.

66. Tomer, J. F. (1998). Organizational capital and joining-up: Linking the individual to the organization and to society. Human Relations, 51 (6), 825-846.

67. Troyer, L. C., \& Younts, W. (1997). Whose expectations matter? The relative power of first- and secondorder expectations in determining social influence. The American Journal of Sociology, 103 (3), 692-742.

68. Verespej, M. A. (2001). A call for civility. Industry Week, 250 (2), 17.

69. Vogt, M. F. (1995). Accelerating organizational performance through an employee bonus plan. Management Quarterly, 36 (2) 20-23.

70. Waters, M. (1999). Thank them and they will follow. New Zealand Management, 46 (10), 33-34.

71. Wayne, S. J., Shore, L. M., \& Linden, R. C. (1997). Perceived organizational support and leader-member exchanges: A social exchange perspective. Academy of Management Journal, 40 (1), 82-111.

72. Weiss, D. (1997). Uncivil wars. Getting Results...For the Hands-On Manager, 42 (5), 3.

73. Westphal, J. D., \& Zajac, E. J. (1995). Defections from the inner circle: Social exchange, reciprocity and the diffusion of board independence in U.S. corporations. Academy of Management Journal, (Best Papers Procedings 1995), 281-285.

74. Williams, K. D., \& Sommer, K. L. (1997). Social ostracism by coworkers: Does rejection lead to loafing or compensation. Personality \& Social Psychology Bulletin, 23 (7), 693-706.

75. Yukl, G., Guinan, P. J., \& Sottolano, D. (1995). Influence tactics used for different objectives with subordinates, peers, and supervisors. Group \& Organization Management, 20 (3) 272-296.

76. Yukl, G. (1994). Leadership in organizations, ( $3^{\text {rd }}$ ed.). Englewood Cliffs, NJ: Prentice Hall.

77. Yukl, G., Fable, C. M., \& Youn, J. Y. (1993). Patterns of influence behavior for managers. Group \& Organization Management, 18 (1) 5-28. 